\title{
THE AUTHORITY OF LAW IN PLATO'S CRITO
}

\section{Antony Hatzistavrou}

\section{Introduction}

The speech of the Laws in the Crito is one of the most discussed and debated texts of Plato's dialogues. ${ }^{1}$ It has been studied from a variety of perspectives. Classical scholars primarily focus on how the speech relates to the overall dialectic of the Crito and debate whether the moral values of the Laws are consistent with Socrates' values as expressed in earlier parts of the Crito and in the Apology. ${ }^{2}$ Political philosophers and historians of political thought discuss the validity and strength of the Laws' arguments for political obligation or possible

I am grateful for comments from Victor Caston, Melissa Lane, Malcolm Schofield and two anonymous referees for this journal.

${ }^{1}$ The Crito is considered to belong to Plato's early dialogues. Some scholars assume that those dialogues contain a philosophical outlook that is in some aspects (for example in its account of the impossibility of akrasia or in its account of the metaphysics of the Forms) different from the philosophy of Plato's middle and late dialogues and that is normally referred to as 'Socratic philosophy' (for a recent defence of that interpretation of Plato's philosophical development see Thomas C Brickhouse \& Nicholas D Smith, Socratic Moral Psychology (Oxford University Press, 2010) at 11-42. Though I accept that interpretation (see Antony Hatzistavrou, “Crito's Failure to Deliberate Socratically” (2013) 63:2 Classical Quarterly 580), it has no significant bearing on my analysis of the speech of the Laws in this article.)

${ }^{2}$ For the interpretation that the values of the speech of the Laws are consistent with Socratic morality see for example, Gerasimos X Santas, Socrates. Philosophy in Plato's Early

Dialogues (Routledge and Kegan Paul, 1979), Richard Kraut, Socrates and the State (Princeton University Press, 1984), and Terence Irwin, Plato's Ethics (Oxford University Press, 1995) at 46-47. For the interpretation that the system of moral values of Socrates and the laws diverge see for example: Gary Young, "Socrates and Obedience" (1974) 19:1 Phronesis 1, Verity Harte, “Conflicting Values in Plato’s Crito" (1999) 81:2 Archiv für Geschichte der Philosophie 117, and Roslyn Weiss, Socrates Dissatisfied: An Analysis of Plato's Crito (Oxford University Press, 1998). 
refinements of those arguments ${ }^{3}$ and examine the relevance of the speech of the Laws to the debate about civil disobedience. ${ }^{4}$

In this article I study the speech of the Laws from a different, jurisprudential, perspective. More specifically, I focus on the Laws' views about the authority of law. I offer new interpretations of their famous 'persuade or obey' alternative and their arguments about their superior moral status and the agreements of the citizens; I explore the rather neglected topic of the mental attitude that they require from their citizens arguing that they are satisfied with reflective acceptance of their authority; and I analyze several implications of their account of the authority of law for their understanding of the relation between law and morality. I approach the speech of the Laws as a historian of legal thought. I am primarily interested in reconstructing the Laws' relevant arguments within their appropriate philosophical and historico-legal context as opposed to assessing their cogency.

For the purposes of my article I take the study of the speech of the Laws from the perspective of the history of legal thought to be important especially for the following reason. ${ }^{5}$ The speech of the Laws provides one of the earliest examples of a philosophical analysis of the theory and ideology of a historical legal system, namely, the legal system of ancient Athenian democracy. That philosophical analysis cannot be properly understood unless it is carefully located within both the context of the Athenian legal system and the context of Platonic philosophy. ${ }^{6}$

\footnotetext{
${ }^{3}$ See, for example, ADM Walker, "Political Obligation and the Argument from Gratitude"
} (1988) 17:3 Philosophy \& Public Affairs 191 and George Klosko, "Fixed Content of Political Obligations" (1998) 46:1 Political Studies 53.

${ }^{4}$ See for example, Gregory Vlastos, "Socrates on Political Obedience and Disobedience" in DW Graham, ed, Studies in Greek Philosophy, vol. 2 (Princeton University Press, 1995) and J Peter Euben, "Philosophy and Politics in Plato's Crito" (1978) 6:2 Political Theory 149.

${ }^{5}$ Of course there are other reasons for which a historian of legal thought may be interested in the speech of the Laws, for example, an examination of the development of Plato's views about the authority of law. I merely highlight in the main text the reason that motivates my study of the speech of the Laws in this article.

${ }^{6}$ Apart from the Crito I also rely heavily on the evidence of the Apology. The evidence of the Apology is relevant for two reasons. First, the Apology is the dramatic prequel to the Crito. Second, in the Apology Socrates finds some legal disobedience morally justifiable which appears to contravene the Laws' claim to authority. (As I explain, however, once we properly understand the Laws' claim to authority, Socrates' attitude towards law in the Apology is consistent with their claim to authority.) I also rely on the evidence of the Laws which is a late dialogue on two occasions (on my analysis of the Laws' understanding of the citizens' 
I proceed as follows. In the first section of the article, I introduce the dialectical context of the speech of the Laws. In the second, I outline the structure of the speech. In the third, I examine the type of behaviour of their subjects that the Laws take to be consistent with respect for their authority. In the fourth, I analyse the mental attitude towards their directives that the Laws expect from their subjects. In the fifth, I explore the Laws' views about the relation between law and morality.

2. The dialectical context of the speech of the Laws

The Crito describes a discussion between the imprisoned Socrates and his long-term companion Crito. The discussion takes place the day before Socrates is to drink the hemlock. Crito tries to convince Socrates to accept the assistance of Crito himself and some other friends of Socrates in escaping from prison and saving himself (44b6-7). He claims that Socrates' escape would be just and courageous both for Crito and Socrates' friends and for Socrates himself. It would be just for Crito and Socrates' friends because they will appear to the many to have fulfilled their duty of friendship to Socrates and not spare money in helping him save his life (44b6-c5). Their assistance would also be judged an act of courage by the many as they would have disregarded the relevant risks involved in order to save their friend (45d9-46a3). Socrates' escape would be just for Socrates as he would frustrate the plans of his enemies to kill him (45c6-9) and would also fulfil his parental duties to raise his children (45c10-d3). Furthermore, given that parental duties are burdensome, if Socrates refuses to fulfil them he would be deemed a coward (45d4-9).

Socrates responds that Crito's arguments rest on two mistaken assumptions. The first is that one should value the views of the many $(44 \mathrm{~d} 1-2)$. The second is that the many have great power to harm since they can cause Socrates' death (44d2-5). Socrates claims that both assumptions are inconsistent with the conclusions of arguments that Socrates and Crito accepted in the past. ${ }^{7}$ The first conflicts with arguments that established that one should value

satisfaction with them and of Plato's attitude towards parricide). Reliance on the Laws is justified since it contains Plato's most focused and extensive analysis of the nature and function of law and thus is indispensable for an understanding of Plato's legal philosophy as a whole. Furthermore, the two occasions on which I rely on the evidence of the Laws do not relate to the main aspects in which the philosophy of the early dialogues is considered to differ from the philosophy of later dialogues (see Brickhouse \& Smith, supra note 1). Finally, on one occasion I rely on the evidence of the Protagoras in order to justify the conceptual framework that I draw on in elucidating the Laws' claim to authority and Socrates' attitude towards the Laws (see infra note 18).

${ }^{7}$ Socrates refers to arguments (logous) that he upheld and cherished in the past (46c1-2) and continuously advocated (see the use of elegeto at 46d1, d7 and 47a12). He implies that Crito's acceptance of the thesis that one should value only the views of the wise (47a6) and 
the views of the wise and not the many (47a2-10). The second conflicts with arguments that established that one should value not merely surviving but primarily living justly (48b4-9).

As I have argued elsewhere, Socrates worries that Crito has lost his commitment to theses that were established in previous arguments because he is emotionally upset at the prospect of Socrates' death. ${ }^{8}$ Socrates tries to strengthen Crito's commitment to the thesis that the views of the many are not really valuable by reproducing a lengthy argument in its support (47a2-48a10). He also gains Crito's agreement that the previous arguments to the effect that living justly is the primary aim in life still hold well. And then he focuses on exploring whether escaping from prison against the wish of the Athenians is a just course of action (48b10-d6).

Socrates clarifies that the assessment of the justness of his potential escape from prison needs to involve two principles. The first is that one should never commit an injustice even in retaliation for a harm received (49b4-d2). The second is that one should abide with one's agreements provided that they are just (49e5-50a5). This means that his escape from prison cannot be just if it is an act of retaliation or if it involves breaking a just agreement. It is at this stage of the argument that Socrates introduces the speech of the personified Laws of Athens.

3. The structure of the speech of the Laws

We may take the overall argument that the Laws develop in their speech to involve the following steps:

Step One (50a6-c4): Socrates' frame of mind. ${ }^{9}$ The Laws try to ascertain Socrates' frame of mind that would lead him to the decision to escape from prison. They claim that (a) Socrates

the thesis that one should value living justly and not merely surviving (48b6) is based on Socrates' previous arguments.

${ }^{8}$ See Hatzistavrou, supra note 1.

${ }^{9}$ Step One does not merely reveal the consequences of Socrates' escape or what his escape might be considered to express but what Socrates knowingly tries to do. That becomes clear from the vocabulary the Laws use: they ask Socrates what 'his mind is directed at' (en nô $i$ echeis) doing (50a9) and whether by the specific action that he is trying to commit, namely, his escape, he 'intends' (dianoêi) to destroy the laws (50b1). The focus on Socrates' frame of mind makes perfect sense in terms of the dialectical exchange between Socrates and Crito before the introduction of the speech of the Laws (for which see section 2 above). Once it is revealed that Socrates intends for his part to destroy the Laws because he believes that he has been treated unjustly (50c1-2), his escape from prison can be validly considered an act of retaliation. Since it is an act of retaliation, then according to the first principle for assessing the justness of Socrates' escape that was agreed between Socrates and Crito at 49b4-d2, it 
would intend to destroy the Laws and more specifically to destroy the rule of law, namely, the effectiveness of the Laws in getting the citizens to pursue the type of action they prescribe. For he would intend to disobey the decision of the court that condemns him to death and the Laws' ability to guide the actions of citizens would be severely diminished if the decisions of the courts are ineffective. In a similar manner he would intend to destroy the city of Athens since no political order can exist when the citizens feel that they can disregard the decisions of the courts. And they also claim that (b) Socrates' reason for intending to destroy the Laws would be the fact that the city committed an injustice towards him by not judging correctly his case and condemning him to death. In other words, Socrates' escape would be a retaliatory action.

Step Two (50c5-51c5): The Laws' superior status. The Laws try to show that, even if it were true that the city committed an injustice towards him, that fact could not be a ground for his attempt to undermine the rule of law. They argue that the Laws have such superior status as begetters and nurturers of the citizens that they should not be harmed by the citizens even when they have wronged them.

Step Three (51c6-52a5): The citizens' agreements with the Laws. In addition to disrespecting their superior status, the Laws claim that if Socrates escaped he would violate his agreements with them. For the Laws allow the citizens to emigrate if they do not like them and whoever stays has agreed by his action of remaining in the city to obey them. The Laws then summarize the main charges that Socrates would be found guilty of if he escaped: disrespect for the supreme status of the Laws and violation of his agreement with them.

Step Four (52a5-53a8): Socrates'supreme satisfaction with the Laws. The Laws argue that there is an additional reason specific to Socrates that make Laws' authority over him particularly binding. The fact that Socrates never left Athens shows his supreme satisfaction with the Laws.

Step Five (53a9-54b2): Prudential reasons against Socrates' escape. The Laws shift to considering the potential benefits that Socrates' escape would bring to him and his family. They argue that there no real benefits. Socrates could not find refuge in a law-abiding city given his reputation as a threat to the rule of law. He could only live in lawless countries like Thessaly in which he would not enjoy the kind of philosophical activity he cherishes and would not be able to provide any decent education to his children.

cannot be just. Step Two will show that it is supremely unjust because the intended retaliation is directed against those one should least harm. 
Step Six (54b3-d2): Summary. The Laws summarise the main points of their speech adding two new considerations. The first is that Socrates has not been, strictly speaking, wronged by the Laws but by humans, namely, the jurors who decided his case. The implication is that the target of his retaliation would be misguided: he would be trying to avenge the Laws by escaping while they are innocent of his plight. The second is that his escape would be punished in the afterlife.

The most informative steps about the Laws' account of their authority are steps two to four. I focus on them in the subsequent two sections.

4. The authority of the Laws (A): the type of behaviour the Laws demand from their subjects

Before proceeding it is useful to clarify that the Laws speak of 'law' (nomos) in a wide sense. They take their arguments to apply to commands of lawfully instituted authorities, for example, commands of military and judicial authorities (see 51b9-c1). And they do not utilise in their speech the distinction between 'decrees' (psêphismata) (that is, enactments of specific scope such as declarations of war that were made by the Assembly or the Council) and 'statutes' (nomoi) (that is, enactments of a wider scope that were made by a specific body of 'lawgivers' (nomothetai)) that was introduced in 403/2 as part of the project of recodification of the laws of Athens. ${ }^{10}$ In reconstructing the Laws' arguments about their authority I will similarly avoid building on any of the aforementioned distinctions and take their arguments to apply to law in a wide sense.

In their attempt to illustrate their supreme status (50c5-51c5), the Laws identify themselves with the city and demand that the citizens persuade (peithein) or do whatever the city commands (51b4). A few lines later, in the second step of their argument, they claim that it is just that the citizens do whatever the city commands or persuade it about where justice lies (51b10-c1). The Laws further elaborate on the 'obey or persuade' alternative in the third step of their argument (51c6-53a8). By reference to the case of a disobedient person who had the option of leaving the city if he did not like its laws but, who, after seeing how the laws of Athens operate, decided to stay (51d1-e1), they claim:

\footnotetext{
${ }^{10}$ For an account of the distinction between psêphismata and nomoi and the exegetical problems surrounding it see MH Hansen, The Athenian Democracy in the Age of
}

Demosthenes: structure, principles and ideology (Blackwell, 1991) at 171-74. 
(T) ...we say that the person who disobeys us does wrong in three ways: because he disobeys us while we are his begetters, and because he disobey us while we have raised him, and because, while he agreed with us that he will obey, he neither obeys nor persuades (peithei) if we do not do anything well, though we propose as an alternative (protithentōn) and do not fiercely demand (ouk agriōs epittatontōn) that he does what we command, and while we allow him to do one or the other of two things (ephientôn duoîn thatera), i.e. to either persuade (peithei) us or obey, he does neither. (51e7-52a3)

On a natural reading of this passage the Laws are making the following claims:

(C1) The citizens have agreed to obey the Laws.

(C2) Persuasion is an alternative to obedience.

(C3) A disobedient citizen may be blamed not only for disobeying the Laws but also for not persuading them.

How do those claims hang together and what do they imply about the legal and moral duties of citizens? To properly answer those questions we need to tackle two issues. The first concerns the meaning of persuasion: do the Laws have in mind successful persuasion or a citizen's attempt to persuade? ${ }^{11}$ The second concerns whether persuasion is a meaningful or only a nominal legal alternative to obedience. I take persuasion to be a meaningful legal alternative to obedience, if it is legally permitted, even if the citizen disobeys; by contrast it is only nominally a legal alternative to obedience if it is only permitted provided that the citizen obeys. Attempts to tackle those two issues have led to a dichotomy. According to one interpretation, the Laws have successful persuasion in mind, treat it as a nominal legal alternative to obedience and hold that the citizens have only a single legal and moral duty, namely, to obey. ${ }^{12}$ According to a second interpretation, whereby 'persuasion' the Laws refer to a citizen's attempt to persuade, persuasion is a meaningful alternative to obedience and legally and morally permit some disobedience. ${ }^{13}$ The dichotomy is false. As I will show, a

${ }^{11}$ There is no grammatical reason why the two occurrences of peithein in T cannot mean 'try to persuade': Greek verbs may have a 'conative' force in the present and imperfect tenses. One may compare the two uses of peithôn in Apology 30a8 and 30e7, where the context reveals that they refer to Socrates' unsuccessful attempts to persuade his fellow-citizens about the importance of caring for their souls. For a comprehensive defense of the possibility of the attempted persuasion reading, see Kraut, supra note 2 at 71-73.

${ }^{12}$ For this interpretation see generally, inter alios, David Bostock, "The Interpretation of Plato's Crito" (1990) 35:1 Phronesis at 1 and Harte, supra note 2.

${ }^{13}$ This interpretation is advanced by AD Woozley Law and Obedience: The Arguments of Plato's Crito (Duckworth, 1979) at 28-61 and Kraut, supra note 2 at 54-90. 
proper understanding of the Laws' account of their authority shows that, though the Laws may treat a citizen's attempt to persuade as a meaningful alternative to obedience, they may still hold that the citizens have an absolute legal and moral duty of obedience.

The problem with the successful persuasion interpretation is that it fails to account for the contrast the Laws draw between themselves and those laws which fiercely (agriōs, 52a1) demand obedience. As Adam remarks, the Laws have presumably in mind laws of authoritarian regimes like tyrannies. ${ }^{14}$

Successful persuasion involves the changing of the minds of legal authorities (for example, in the context of the Athenian democracy, the Athenian assembly, the lawgivers (nomothetai) or the People's courts) on the basis of arguments presented to them. When the Laws claim that, in contrast to their fierce counterparts, they allow persuasion, they obviously do not mean that only in the Athenian democracy do legal authorities actually change their minds when confronted with compelling arguments. For clearly tyrants as well may change their minds about a legal directive they have issued on the basis of arguments presented to them. Neither is it plausible to assume that the Laws claim that only in the Athenian democracy is the relevant change of mind of legal officials lawful. In this case the Laws would be making the (rather controversial) claim that in tyrannies, for example, the tyrant's being persuaded is unlawful (i.e. goes against tyrannical laws). If that were so, those laws would be fierce towards those who possess legal power. However, the Laws clearly relate the fierceness of laws to what they allow the subjects to do and not to what they allow the rulers or legal officials to do (i.e. change their minds).

I suggest that when the Laws contrast themselves to fierce laws, they mean that, in the Athenian legal system, persuasion is a legally permitted option for those who disagree with a certain law or a certain directive of a lawfully instituted authority. The Athenians have a legal right to challenge a certain law or directive and there is a lawfully instituted procedure for following-up their challenge. By contrast, in other legal systems, the citizens may lack a legal right to challenge laws or legal directives. In tyrannical regimes, for example, the citizens may have only one legally permitted option, i.e. to obey the law. They may, of course, be physically able to challenge the law (for example, they may stand up in front of a tyrant and argue that his commands are unfair) and even succeed in changing the mind of the tyrant. But in this case their challenge is not legally permitted and is thus unlawful. Fierce laws do not allow, in the sense of recognizing as lawful, challenges to specific laws or directives.

If that is the point of contrast between the Athenian laws and their fierce counterparts, then the Laws allow, in the sense of finding lawful, the citizens' attempt to persuade, that is, the citizens' trying to change the mind of democratic legal authorities. According to fierce laws, the very attempt of persuading legal authorities is unlawful. And that is precisely the reason why they are fierce. So, the fierceness or leniency of laws relates to whether they legally permit the attempt of the citizens to change them.

\footnotetext{
${ }^{14}$ James Adam, Platonis Crito (Cambridge University Press, 1891) at 70. In support of his claim Adam cites Gorgias 510b7 and Republic 329c4.
} 
It is sometimes argued that the 'attempt to persuade' interpretation fails to account for the way the 'persuade or obey' alternative applies to the case of Socrates. Let me examine two relevant arguments. First, Bostock has argued that the Laws cannot meaningfully accuse Socrates of failing to try to persuade them if he chooses to escape. For in the Apology Socrates tried to convince the jury that a fine and not death may be a more appropriate penalty (38ab1-10). Bostock finds the retort that Socrates should have explained in addition that his escape from prison is just quite unreasonable. ${ }^{15}$ I disagree. As I later explain, the 'persuade' alternative has a significant function: it enables the Laws to bring the content of their commands in line with the citizens' morality. ${ }^{16}$ Thus, the Laws can reasonably expect from a citizen who attempts to persuade them to provide, as far as possible, a complete account of the nature and gravity of the injustice which he thinks that the Laws commit. ${ }^{17}$ It is also reasonable to assume that the gravity of the injustice of the Laws' commands may be partly assessed on the basis of whether that injustice outweighs any considerations in favour of respecting their authority. ${ }^{18}$ If a citizen judges based on his moral principles that the

${ }^{15}$ Bostock, supra note 12 at 16 . The retort is made by Kraut, supra note 2 at 89-90.

${ }^{16}$ See section 6 below.

${ }^{17}$ So, for the Laws persuasion involves the formulation and presentation of arguments that aim to be as complete as possible about the moral deficiencies of specific legal commands. Though the import of the speech of the Laws to the contemporary discourse about civil disobedience is beyond the scope of this article, it is clear that the Laws would not count as attempts to persuade them actions the primary function of which is to express discontent such as protests or marches.

${ }^{18}$ In the remainder of the article I draw on the conceptual framework of contemporary philosophical discussions about practical reasoning in order to make sense of both the Laws' claims about their authority in their speech and Socrates' attitude towards the Laws. For example, I speak of reasons or considerations for or against courses of action, of some reasons or considerations outweighing, defeating or overriding others, of the balance of reasons and of judgements about what one should do all things considered. I do not think that it is inappropriate to deploy that conceptual framework for my exegetical purposes. That conceptual framework is perfectly compatible with (and in fact it could be arguably traced back to) Socrates' account of what practical reasoning involves. In the Protagoras Socrates argues that in deciding about how to act people 'weigh up' (stêsas en tôi zugôi, 356b2) a variety of considerations about the goodness and badness of alternative courses of action available to them and act on their overall judgement about the value of those considerations (356a8-c3). (In the course of the relevant argument goodness is equated with pleasure and badness with pain but it is debatable whether Socrates genuinely espouses hedonism in the 
injustice of a command does not outweigh the considerations favouring respect for the authority of law, then he may not be overall justified by his own moral standards in disobeying the unjust command (though he may be justified in trying to persuade the Laws to retract the command while he continues to obey). By contrast, if a citizen judges based on his moral principles that the injustice of a command is so serious as to defeat any considerations in favour of respecting the authority of law, then he should make it clear during his attempt to persuade, if his explanation of the injustice of the command is to be complete. At least the Laws can reasonably expect that a conscientious citizen will try to provide a relevant complete explanation. Socrates' own explanation of why he would disobey an imaginary decision of the court which would prohibit him from philosophizing is a case in point (Apology 29c6-30c2). By contrast, his willingness to accept the death penalty in the Crito indicates that he does not judge based on his moral principles that the injustice of the decision of the court to condemn him to death is of such gravity as to justify breaking the law which prescribes that the decisions of the courts be binding. ${ }^{19}$

Second, Kahn argues that understanding persuading in T as "trying to persuade" does not square with Socrates' previous use of the concept of persuasion in the Crito. ${ }^{20}$ Before the speech of the Laws is introduced Socrates invites Crito to consider whether by leaving prison while they did not persuade the Athenians they would be ill-treating people (49e8-50a1).

Protagoras.) In fact for Socrates one's well-being depends precisely on the relevant art of measurement (metrêtikê technê) of the value of the various reasons for or against different courses of action that enables one to arrive at correct overall judgements about how to act (357a5-b5).

${ }^{19}$ As I explained in the previous footnote, Socrates' decisions are based on his judgements about the balance of relevant reasons for action. And, as he makes clear in the Crito (see section 2 above), those judgements are guided by considerations of justice. So, the contrast between Socrates' willingness to disobey an imaginary decision of the court that prohibited him from philosophizing and his willingness to accept the decision of the court that condemned him to death must be explained by reference to his judgement that the injustice of the former decision of the court is greater than the injustice of the latter decision. Why would he take the former decision to be more unjust? A possible answer is that he believes that the decision of the court to prohibit him from philosophising distorts the value of philosophy. By contrast, an occasional miscarriage of justice, though deeply regrettable, need not entail that the Athenian laws distort any values (for example, it need not entail that they distort the value of justice). This explanation is consistent with the Laws stressing in step six of their argument that the injustice that Socrates suffers is not their doing but rather the result of actions of individuals (54b9-c2).

${ }^{20}$ Kahn, supra note 2 at $40 \mathrm{n} 14$. 
Kahn suggests that we should also treat 'persuading' as a success verb in the speech of the Laws in agreement with the use of the term in the aforementioned passage. We need not follow Kahn's suggestion. Socrates' reference to the unsuccessful persuasion of the Athenians at 49e8-50a1 need not be a forward-looking reference to the 'persuade or obey' alternative which is mentioned in the Laws' speech and which, as I explained in the previous paragraph, invites a complete explanation of the injustice that the Laws commit based on the citizens' moral standards. Rather it may be understood as a backward-looking reference to the way Socrates previously described his imaginary escape from prison. "Leaving prison without persuading the Athenians" is a description semantically equivalent to the description "leaving prison against the will of the Athenians" that Socrates used when he referred to his imaginary escape at 48b11-c1 (mē aphientōn tōn Athenaiōn) and at 48e3 (akontōn Athenaiōn). This semantic equivalence is supported by the general link Socrates establishes between "doing $X$ without succeeding in persuading $Y$ " and "doing $X$ against $Y$ 's will" at 48e3-5: Socrates claims that he values persuading Crito that he remain in prison more than remaining in prison against Crito's will (akontos). So, the failure to persuade mentioned at 49e8-50a1 should be understood as referring specifically to Socrates' failure to convince the Athenians at his trial that he should walk free. Since Socrates failed to persuade the Athenians that he should walk free, his imaginary escape could be described as an action that goes against the will of the Athenians. By contrast, persuasion in $\mathrm{T}$ and elsewhere in the speech of the Laws refers to the citizens' attempt to provide a complete explanation of the injustice of a legal command. As I explained in the previous paragraph, the relevant complete explanation of the injustice of the decision of the court to condemn Socrates to death was not undertaken by Socrates.

I conclude that we should reject the successful persuasion interpretation and understand that the Laws permit that the citizens may try to persuade. The disobedient citizen the Laws refer to in $\mathrm{T}$ is someone who disobeys a specific law or legal directive without trying to persuade the Laws to change or annul that law or legal directive. This interpretation explains why the Laws relate the citizen's failure to keep his agreement not only to his disobedience but also to his not trying to persuade them. That citizen is blamed for not taking up a legally permitted option available to him but opting for a legally forbidden option, namely, ordinary disobedience which is not accompanied by an attempt to persuade.

The language the Laws use in order to describe the normative situation of a citizen with respect to their commands strongly suggests that they intend persuasion (understood as the citizens' attempt to persuade) as a meaningful alternative to obedience. ${ }^{21}$ In $\mathrm{T}$ the Laws claim that they "propose as an alternative" and "do not fiercely demand" obedience but "allow" the citizen to either obey or persuade. I think that the motive for resisting the interpretation that persuasion is a meaningful alternative to obedience relates to the presumption that, if the Laws permit that a citizen may persuade while he disobeys, they must

${ }^{21}$ In the remainder of the article I will understand by 'persuasion' the citizens' attempt to persuade. 
permit at least some disobedience. That is, (C2) (persuasion is an alternative to obedience) is presumed to entail:

(1) (i) The Laws permit that a citizen obeys and (ii) they permit that he tries to persuade and does not obey

(ii) in (1) is interpreted as involving a conditional offer, namely, that the citizen is permitted not to obey provided that he tries to persuade. ${ }^{22}$ That conditional permission to disobey, however, is consistent neither with the gist of the Laws' argument about their supreme status, in which, as I will explain shortly, the Laws demand that the citizens obey all their commands, nor with the content of the citizens' agreement as described in (C1) (the citizens have agreed to obey the Laws) in which persuasion is not mentioned.

But (1) is not the only possible reading of C2. C2 may be taken to entail:

(2) (i) The Laws permit that a citizen obeys and, (ii) if he does not obey, the Laws permit that he persuades

(ii) in (2) does not entail that the Laws permit disobedience when accompanied by persuasion. It is compatible with (ii) in (2) that there is a legal norm which demands that the citizens obey all their commands. So, it is compatible with (ii) in (2) that the person who disobeys may be prosecuted for his disobedience even if he tries to persuade. Rather (ii) in (2) indicates that in cases in which a citizen's disobedience precedes or is contemporaneous with his attempt to persuade his disobedience does not have certain legal consequences. More specifically, it is not considered a legal ground for preventing him from trying to demonstrate a relevant legal injustice; for example, during his trial for his disobedient behaviour he may argue that the legal directive he disobeyed was unjust. And, if he is successful in his attempt to persuade, he need not be punished for his disobedience (he may be excused or pardoned). But, if the attempt to persuade the Laws fails, the citizen may be punished. ${ }^{23}$ So, obedience is not only a legally permitted option but is also always required, unless the Laws retract their

${ }^{22}$ Thus, (ii) in (1) is understood along the lines of the 'package-deal' reading of conjunctive permissions (for which see Robert van Rooy, "Permission to Change" (2000) 17:2 J of Semantics 119 at $133 \mathrm{ff}$.) and not according to a 'free choice permission' reading (which would have the undesired consequence that the Laws permit the citizens to disobey even though they do not try to persuade).

${ }^{23}$ Given the flexibility of the verdicts of the People's Courts that I mention below, the punishment of the person who disobeys but attempts to persuade need not be a foregone conclusion (though it would be the outcome one normally expected). 
legal directive (say, as a result of a citizen's attempt to persuade them). In other words, obedience is a citizen's absolute legal duty. ${ }^{24}$

I suggest that persuasion could take place in a variety of legal contexts within the Athenian democracy. That suggestion is supported by the interrelations of the legal procedures of the Assembly and the People's courts or indeed other democratic institutions like the Council or the lawgivers (nomothetai) especially after 403/2BC. For example, a proposal to repeal a statute could be presented to the Assembly and then discussed by the board of lawgivers; but it could be in principle challenged by a 'public prosecution for proposing and carrying an unsuitable statute' (graphē nomon mēe epitēdeion theinai) on which a court would reach a verdict. At any legal stage persuasion may be used. I believe that the Laws present persuasion as a general jurisprudential principle which corresponds to a distinctive feature of the Athenian legal system, namely, its flexibility and openness to legal change. ${ }^{25}$ Athens allowed for its laws (decrees or statutes) to be revisited and changed (in some cases even within a few days, as Thucydides' account of Athens' reaction to the Mytilenian revolt shows (3.36)). After 403/2 Athens had a nexus of established legal procedures for the revision of laws, namely, the 'review', 'repeal' and 'inspection' laws ${ }^{26}$ and for the scrutiny of laws, most notably, 'public prosecution for unconstitutional decrees' (graphe paranomōn) and 'public prosecution for proposing and carrying an unsuitable statute'. As Hansen clarifies the latter two procedures could be used not only against statutes or decrees inconsistent with the rest of the laws but also against statutes or decrees which, though consistent with the body of Athenian law, "were regarded as unsuitable or, more bluntly, damaging to the democracy and the people". ${ }^{27}$ Furthermore, any Athenian citizen could bring a 'public indictment' (eisaggelia) to the Assembly or the Council against a magistrate and thus question decisions of lawfully instituted authorities. Finally, the People's

${ }^{24}$ The fact that obedience is a citizen's absolute legal duty does not entail that the Laws' recognising the attempt to persuade as a legally permitted option has no significant practical consequences for the citizens. Successful attempts to persuade result in legal changes. But even if their attempt to persuasion failed, the citizens who disobeyed but tried to persuade could reasonably expect not to be treated as harshly as those who disobeyed without trying to persuade (52e7-52a3) and might even avoid punishment altogether (see text at note 23 above).

${ }^{25}$ For a recent analysis of this feature of Athenian democracy see Melissa Schwartzberg, “Athenian Democracy and Legal Change” (2004) 98:2 American Political Science Rev 311.

${ }^{26}$ For which see MH Hansen, "Athenian Nomothesia" (1985) 26:4 Greek, Roman and Byzantine Studies 345.

${ }^{27}$ Hansen, supra note 10 at 175. 
courts did not observe the principle of stare decisis or any rules of statutory interpretation, a fact which further underlies the flexibility (and unpredictability) of their verdicts. ${ }^{28}$

I stated that the argument about the Laws' supreme status shows that the Laws cannot tolerate any disobedience. Let me explain. The Laws' account of their supreme status strongly suggests that they consider any act of legal disobedience incompatible with their authority. The Laws rely on ideological constructs which purport to illustrate the legitimacy of their authority: (a) they identify themselves with the city (polis) and the fatherland (patris) (51a2-3, 51b10, 51d8, 52b2, and 52b8-c1); and (b) they take the status of the city and the fatherland to be analogous, though vastly superior, to the status of parents (51a8 and 51c2) and masters of slaves (50e4 and 50e8). Those ideological constructs are rhetorically powerful and the Laws take them for granted without making an effort to support them by philosophical arguments. ${ }^{29}$ The Laws claim that because of their vastly superior status the citizens should, inter alia, 'yield' (hupeikein, 51b3) to them and do (poiêteon, 51b7) whatever they command no matter how onerous (51b4-7). So, there is a fundamental legal norm that demands that the citizens obey all legal commands. But obedience is not only the citizens' legal duty but also their moral duty. For the Laws claim that it is just (51b7-8) to yield to their commands and that disobedience is an act of extreme impiety (51c1-3). There is no room in their legal ideology for morally permissible acts of legal disobedience. Only one moral prescription captures their claim to authority: 'the citizens ought to conform to all legal commands'. Given that their authority is supreme, the citizens' moral duty to obey a specific legal command is absolute: it cannot be defeated by any other moral considerations though it could be cancelled in case the Laws retract their command (which is the end of the citizens' attempt to persuade).

A paradox emerges at this point. The Laws acknowledge that at least in some cases what they command might not actually be just and that is why they allow the citizens to persuade them about where justice lies (51c2). But if the Laws hold that at least in some cases what they command is unjust, how can they also hold that in those cases it is still unjust and

${ }^{28}$ See SC Todd, The Shape of the Athenian Law (Oxford University Press, 1993) at 60-62.

${ }^{29}$ The validity of both (a) and (b) is questionable. One of the (many) problems surrounding them concerns the possibility of significant legal change. (a) has the problematic implication that significant legal change (say, constitutional change) entails change of the fatherland. Do the Laws hold that, for example, when the Third Tyrants came to power, the fatherland changed? (We should note that 'fatherland' has different connotations from 'city' so even if the Laws, like Aristotle, equated the city with its constitution, the equation of the constitution with the fatherland would remain dubious). The possibility of significant legal change also poses problems for (b): what does the analogy of the fatherland with one's parents imply for someone who was born under the regime of the Thirty Tyrants but raised in democracy? Which of the two regimes counts as 'fatherland' for that person? 
impious not to obey their command? I believe that their argument from their supreme status provides the key to resolving the paradox: due to their supreme status the Laws can change the balance of moral reasons of the citizens. Let me first clarify what the Laws may mean when they acknowledge that a command of theirs may be unjust. They cannot possibly mean that justice requires that the citizens do not conform to their command for, as we have seen, they hold that disobedience is unjust and impious. I suggest that they mean that if one 'brackets' or leaves aside the consideration that they have issued a command, for example, the command that Socrates be punished to drink the hemlock, the balance of all other relevant reasons shows that it is unjust that Socrates be punished. If it is unjust that Socrates be punished, then the citizens should abstain from thus harming Socrates and Socrates himself should not drink the hemlock. The argument from the supreme status of the Laws shows that they, however, have the ability to change the relevant balance of reasons for both Socrates and his fellow citizens by issuing a command. Once the consideration that the Laws command that Socrates be punished is taken into account, then the balance of reasons changes and both Socrates and his fellow citizens are prohibited from acting in ways that may prevent the punishment from taking place. ${ }^{30}$ So, from the Laws' point of view, no act of legal disobedience can ever be morally permitted.

To sum up, according to the Laws, the citizens have two legally permitted alternatives when faced with a legal command: to either obey it or try to persuade the Laws about its substantive injustice. This does not mean, however, that disobedience is legally protected: the disobedient citizen may be prosecuted. Furthermore, the Laws believe that because of their supreme status all their commands ought to always be obeyed. Thus, obedience is also an absolute legal and moral duty of the citizens. But the fact that a citizen has disobeyed is not a legal ground for blocking his attempt to persuade and in case his attempt to persuade is successful he may not be punished for his disobedience. ${ }^{31}$

${ }^{30}$ For a relevant use of the distinction between what a subject ought to do given a legal command and what a subject ought to do in the absence of a relevant legal command see John Gardner, "Law as a Leap of Faith" in Law as a Leap of Faith Essays on Law in General (Oxford University Press, 2012) at 1.

${ }^{31}$ The Laws and Socrates disagree about the moral permissibility of legal disobedience. As I have argued, the Laws never morally justify any legal disobedience while, on the evidence of the Apology, Socrates believes that at least some legal disobedience is morally justified, for example, he would be justified in disobeying a legal directive preventing him from doing philosophy. But Socrates' belief would not result in ordinary disobedience which the Laws condemn. The master of the dialectic would make his disagreement public and not pass over an opportunity to persuade the Laws about the injustice of their commands. For example, in the event of a legal directive forbidding him to do philosophy he would continue to crossexamine his fellow-citizens in public places, like the agora, and, if brought to trial, he would 
5. The authority of the Laws (B): the mental attitude the Laws demand from their subjects

As we have seen, in their argument about their supreme status, the Laws identify their supreme status as an absolute moral reason for the citizens to obey. We may call this reason an 'attitude-independent' moral reason. The supreme status of the Laws is a moral reason for the citizens to obey irrespective of the citizens' mental attitude towards the Laws, for example, irrespective of whether the citizens believe that the Laws have supreme status. In T the Laws also identify what we may call an 'attitude-dependent' moral reason to obey that the citizens have, namely, the fact that they have agreed to obey. The Laws clarify that, by remaining in Athens after they have become familiar with the Athenian legal system and its values, the citizens have agreed to obey all legal commands (51e2-5). How do the Laws understand the citizens' agreement to respect their authority? Addressing that issue sheds light on another aspect of the Laws' account of their authority: the type of mental attitude towards their authority that the Laws demand from their subjects. ${ }^{32}$

try to demonstrate the injustice of the relevant legal directive. In doing so he would be pursuing the legally permitted option of attempting to persuade the Laws about where justice lies by reference to his moral standards.

${ }^{32}$ Does it make sense to say that the Laws 'demand' from the citizens not simply a particular type of behaviour, namely, conformity to their commands, but also a particular type of mental attitude towards their commands, namely, agreement with their commands. I think it does. The Laws stress that they publicly proclaim (proagoreuomen) that any citizen who, after he has gone through the legal process of public investigation (dokimasthêi) (which confirmed his citizenship rights) and has understood how the public affairs are managed and the laws operate, is not satisfied with the Athenian legal system is totally free to leave the city; and that they take anyone who does not take that opportunity to thereby agree (with his actions) to obey them while knowing how the laws operate $(51 \mathrm{~d} 2-\mathrm{e} 5)$. The fact that the Laws make a public proclamation that the citizens are free to leave the city if unsatisfied with them after they have come to know them indicates that the Laws do not want to rule over citizens who either feel oppressed or simply conform to them without any reflective understanding of the workings of the Athenian legal system. Rather it is natural to interpret them as demanding that the citizens understand the legal system, that whoever is unsatisfied with it after he has come to know it leaves the city and that therefore whoever stays does not merely conform to 
In their speech the Laws focus on Socrates' mental attitude towards their authority. So, in order to clarify their understanding of the citizens' agreement to respect their authority, I will examine their account of Socrates' agreement. As I explain, their account of Socrates' agreement applies to the agreement of all citizens. ${ }^{33}$

It is clear that the Laws do not take Socrates' attitude towards their authority to have been the attitude of an oppressed subject. They claim that Socrates never showed any interest in escaping from Athens and its laws (52b1-c1). Furthermore, they allow anyone who does not like them to leave the city (51d4-5) and thus understand anyone who stays to do so willingly. Neither do they believe that Socrates' conformity to their directives was unreflective. They stress that he had ample time to get to know and understand the workings of the Athenian legal system (52e2-5).

Do the Laws believe, as some scholars have maintained, that Socrates obeys because he believes that the Laws are on the whole good and just and that the city would be wellgoverned if their authority were respected, or, in other words, that he morally endorses their claim to authority? ${ }^{34}$ Two interconnected considerations cast initial doubt over that interpretation. First, while the Laws refer to Socrates' praise of the laws of Sparta and Crete (52e5-53a1), nowhere in their speech do they mention a similar overall praise of the laws of Athens. ${ }^{35}$ Secondly, instead of explaining Socrates' agreement to obey them by reference to

their commands but conforms while having a particular mental attitude towards their commands, namely, while having agreed to do so.

${ }^{33}$ Using Socrates as a model for elucidating the citizens' mental attitude towards the Laws is perfectly legitimate since the Laws themselves acknowledge that Socrates' agreement with them was the most paradigmatic of the agreements of the Athenian citizens (52a3-8).

${ }^{34}$ See for example Kraut, supra note 2 at 180.

${ }^{35}$ Socrates repeatedly praised the laws of Sparta and Crete and not simply the two cities' observance of the rule of law (see eunomeisthai at 52e6). This becomes clear from the conclusion of the argument in the context of which the Laws refer to Socrates' attitude towards the laws of Sparta and Crete. Their conclusion is that, despite his praise for the latter, Socrates was supremely satisfied with the city and the laws of Athens (53a3-4). The identification of the city with its legal system suggests that the Laws' conclusion is that Socrates was supremely satisfied with the governance of Athens and not simply with the fact that the city had $a$ legal system the authority of which was respected. So, if the contrast that they intend to draw between Socrates' satisfaction with Athens and his praise of Sparta and Crete is to be relevant, they must mean that he praised the fact that the latter were wellgoverned and not simply the fact that they had laws which their citizens observed. (See also 
his expressed belief in their overall justice and goodness, they infer Socrates' agreement with them from his actions, namely, his remaining a resident of and having children in Athens. ${ }^{36}$

The relevance of those two interconnected considerations becomes clear once we clarify the point of the Laws' claim that Socrates has agreed to their authority "by action and not by logos" (ergōi all' ou logōi (52d6)). ${ }^{37}$ By 'agreements (homologiai) by action' (subsequently, 'agreements A') the Laws refer to the actions of residing and having children in Athens. According to the Laws, for any citizen to perform those actions is for him to agree to respect the authority of the Laws (51e4-52a3). The citizens' agreements $\mathrm{A}_{\mathrm{A}}$ are sufficiently reflective and should not be equated to habitual acquiescence to the Laws' authority. As the Laws clarify, they count a citizen's remaining in Athens as an agreement ${ }_{A}(51 \mathrm{e} 4)$ only after he has familiarised himself with Athens' judicial and overall legal system (51e2-3) and become aware that he is free to emigrate if he is not satisfied with the Athenian laws $(51 \mathrm{~d} 4$ e1).

Logos in Greek covers a variety of concepts like speech, reason and argument. By agreements by logos (subsequently 'agreementsL') the Laws do not refer to singular speech acts with a certain illocutionary force similar to that of promises. That is, they do not refer to one's explicit promise to obey the Laws or to oaths of allegiance. If they did, they could not have claimed that Socrates did not agree by logos to obey them (52d6). For in their speech they have already referred to Socrates' promise in the Apology to obey the decision of the court and not run away (52c6-9). And they have similarly mentioned the legal process of 'public investigation' (see dokimasthêi at 51d3) after which the Athenian youth expressed their allegiance to the laws of Athens in the ephebic oath. Neither should they be understood to use logos in the sense of 'reason' and thus imply that Socrates' agreements with them were not the result of rational consideration. That would have been a striking claim to make about someone who repeatedly praised the examined life and claimed to always follow nothing other than the argument which appears best to his reasoning (45b4-6). Obviously Socrates

Kraut, supra note 2 at 177-78 and MC Stokes, Dialectic in Action: An Examination of Plato's Crito (Classical Press of Wales, 2005) at 169 for more detailed defence of this interpretation.) ${ }^{36}$ The Laws take Socrates to be satisfied with two types of laws, those which govern marriage and the form of education in the city (50d1-e1). (One need not infer, though, that he agrees with the content of education: he claims to be happy with the law ordering his father to train him in music and gymnastics, not with the actual training he received.) But that clearly does not entail that he finds the Athenian laws as a whole good and just.

${ }^{37}$ M Lane (“Argument and Agreement in Plato's Crito" (1998) 19:3 History of Political Thought 313) stresses the importance of the distinction between erga and logoi for an understanding the speech of the Laws, though her interpretation differs significantly from the one I advance. 
conformed to the laws of Athens for good reasons of which he was aware and could explain in discussion.

Rather by logos they refer to an argument (normally, though not necessarily, presented in a speech and delivered in a public place) which demonstrated their merits. So, a citizen who praises them may be considered to agree by logos with them. This understanding of agreements $\mathrm{S}_{\mathrm{L}}$ is consistent with Socrates' contrast between logos and action in the Apology. Socrates utilises the contrast on two occasions. First, he claims that he will provide actions (erga) and not logoi as great evidence that if he engaged in politics he would be destroyed, since the jury prefers the evidence of actions (32a4-5). Secondly, he claims that in refusing to obey the command of the Thirty and arrest Leon from Salamis he showed by action and not by logos that he did not value life more than justice (32c8-d4). In both cases by logos he does not refer to singular assertions of the type 'I would be destroyed if I engaged in politics' or 'I do not value survival more than justice' but rather to arguments that demonstrate the prudence of abstaining from politics or the superiority of justice. At 32a4-5 Socrates implicitly contrasts two types of consideration that have strong evidential value and chooses the one that the jury trusts, namely, consideration of his actions. It is unlikely that he believed that mere assertions to the effect that engaging in politics is a dangerous enterprise have any value as evidence. But, given the value that he ascribed to the examined life, we can safely assume that, in contrast to the jury, he would consider arguments which demonstrated the risk of engaging in politics as having significant evidential value. ${ }^{38}$ In a similar vein at $32 \mathrm{c} 8$-d4 his point is that he did not merely argue (presumably in many dialectical exchanges) that justice is more important than mere survival but actually acted on his dialectically tested belief. ${ }^{39}$ Thus, I suggest that, in the Crito, the Laws understand that for a citizen to agree by argument with their claim to authority is for him to put forward arguments (in the case of Socrates, dialectical arguments) which demonstrate the moral merits of the Athenian laws. By denying that Socrates agreed with them by argument the Laws deny that Socrates ever put forward dialectical arguments that demonstrated their overall merits, in sharp contrast to the praise he reserved for the laws of Sparta and Crete (though he continued to live in Athens and accept their authority).

One could object that the best explanation for Socrates' agreeing by action with the Laws is that he reasoned after careful dialectical examination that the Laws were on the

\footnotetext{
${ }^{38}$ It is hard to resist the impression that Socrates intends an implicit rebuke of the jury's reliance on erga when he invokes the contrast between erga and logoi at 32a4-5. The rebuke would be groundless if by logoi he meant mere assertions as opposed to arguments supported by the elenchus.

39 The specific type of dialectical arguments that Socrates uses are known as 'electic' arguments. For an account of the Socratic elenchus, see Gregory Vlastos, "The Socratic elenchus: method is all” in Myles Burnyeat, ed, Socratic Studies (Cambridge University Press, 1994) 1.
} 
whole good and just. On this line of argument Socrates could not have accepted the authority of the Laws without morally endorsing them.

This argument from best explanation fails. First, there appear to be reasons which can explain Socrates' acceptance of the authority of the Laws equally well as his alleged belief in their overall goodness and justice. For example, on the evidence of the Apology (31d4-32a3) we may ascribe to him the belief that accepting the authority of law and refraining from politics was his best chance of surviving so as to promote justice. Furthermore, kinship affection for his fellow-citizens (30a5) and his belief that the people in every city are as bad as the Athenians in safeguarding justice (31e3) may explain why he did not find immigrating to another city appealing.

Secondly, an overall moral endorsement of the Athenian laws would in effect be a moral endorsement of the legal basis of the Athenian democracy. The Laws' description of the content of the citizens' agreements ${ }_{\mathrm{A}}$ makes this link inextricable. For they take the person who agrees to their authority by remaining in Athens to be aware (horōn) of the manner (tropon) in which justice is administered and in general the city is governed (51e1-5). Thus, the relevant 'manner' must include reference to the legal right of the many to pass judgement on trials and to decide on public policy. But Socrates has very strong reasons to be dissatisfied with a system that puts political power in the hands of the many. As we saw in section 1, Socrates believes that their views lack any value and that one should not rely on them when one makes practical decisions (48a5-b9). So, it is doubtful whether a belief in the overall goodness and justice of the Athenian laws would be a plausible explanation for Socrates' acceptance of their authority. ${ }^{40}$

Another consideration in favour of taking Socrates to endorse the authority of the Laws may be based on the Laws' claim in step four of their argument that he was supremely satisfied (êresken: imperfect tense of areskein) with them (53a3-5). On that interpretation Socrates' supreme satisfaction would be the result of his conclusion that they are on the whole good and just after critical examination of their moral value. But that is not the most plausible interpretation of what the Laws may have in mind when they claim that Socrates is supremely satisfied with them. To see that we need first to distinguish between two different conceptions of what the subjects' satisfaction with the laws of their city may involve that we find in Plato's legal philosophy.

In the third book of the Laws Plato refers to small communities composed out of several settlements or clans that were ruled patriarchically. The laws of those communities were an agglomeration of the laws of the different clans of which they were composed. Plato claims that the members of each of these clans were satisfied with (areskein) the laws that had their origins in the customs of their clans (681c). Their satisfaction was reflective though not critical. It was reflective because they were able to discriminate between laws originating

\footnotetext{
${ }^{40}$ I explain in more detail the authoritarian and anti-democratic character of the political philosophy of Plato's early dialogues in Antony Hatzistavrou, "Socrates' Deliberative Authoritarianism" (2005) 29:75 Oxford Stud in Ancient Philosophy 75.
} 
in the customs of their clans and laws originating in the customs of other clans and were satisfied with the former but not with the latter. But it was not the result of critical deliberation about the value of the customs of their clans. Rather the source of their satisfaction was traced to what they found congenial because of their upbringing: "the fathers of each clan in due course stamped upon their children and children's children their own cast of mind" (681c). For convenience I call the type of satisfaction with their laws that the members of those clans had 'experiential' satisfaction. It is best understood as the lack of desire to change the law which need not be accompanied by any critical appreciation of its moral value or practical efficiency.

The satisfaction of the members of those clans with their laws may be contrasted to the satisfaction with law Cleinias refers to later in the third book of the Laws. Cleinias claims that he and another nine people from Cnosos have been entrusted with constructing a legal framework for a colony. They have been instructed to select laws, not only from Crete but from other places, which they are satisfied with (areskousin, 702c6). Their satisfaction with these laws derives from an appreciation of their comparative value (see beltious, 702c7). Cleinias suggests that he proceeds by constructing, with the help of Megillus and the Athenian Stranger, a theoretical legal framework that will help him in selecting the appropriate laws for the Cretan colony (702c7-d2). Thus, the laws that Cleinias will be satisfied with are those which will survive philosophical scrutiny. For convenience I call that type of satisfaction 'reason-based' as it denotes a type of critical appreciation of the reasons that exhibit the value of a system of laws and is different from the mere of lack of desire to change the law.

In their speech the Laws are not concerned with 'reason-based' satisfaction but focus exclusively on experiential satisfaction. They attempt to establish their claim that Socrates was most satisfied with them by reference to his conative attitudes towards them and not his arguments about them. Their claim that no desire to get to know (eidenai) another city and legal regime ever occurred to him (52b8-9) is most revealing in this respect. The Laws do not accuse Socrates of lack of intellectual curiosity. Their point is not that he was not interested in acquiring propositional knowledge of the legal regimes of other cities. In fact, they later indicate that he had sufficient propositional knowledge of other legal regimes since, as we have seen, they claim that he believed that Sparta and Crete had good laws. Their point is rather that he never desired to become acquainted with another legal regime by living under its jurisdiction. In other words, he never desired to experience life under a different jurisdiction since he was satisfied with his life under the jurisdiction of the laws of Athens. They mention no critical reasons (for example, the comparative advantages of Athenian laws over the laws of other cities) which may have convinced Socrates about their moral or pragmatic value. They are only interested in showing that he was experientially satisfied with their authority.

Furthermore, in order to establish their claim that Socrates was supremely (experientially) satisfied with their authority they do not adduce as evidence any signs of Socrates' strong commitment to the Athenian laws. For example, they do not argue that Socrates showed zeal in implementing or promoting the spirit of the Athenian laws (by, say, 
motivating people to go the Assembly and vote on public policy issues). Rather what they mean by Socrates' supreme satisfaction with Athens and its laws is simply his total lack of interest in changing his condition as a citizen of Athens.

To sum up, the Laws' claim that Socrates was supremely satisfied with them does not entail that he believed in their overall justice and goodness and morally endorsed their authority. Furthermore, we have no reasons to think that a belief in the overall justice and goodness of the Laws is the best explanation for Socrates' attitude towards their authority.

I suggest that the Laws are best understood as taking Socrates to merely accept their authority. His acceptance is willing and reflective but it is not accompanied by a belief in their overall justice and goodness. Rather, as I have already explained, it may be motivated by his general political apathy, his kinship affection towards his fellow Athenians and his belief that the moral character of the many in any other city is as bad as the moral character of the Athenians. Willing and reflective acceptance of their authority is all that his agreements $_{A}$ to obey them involve and the Laws do not demand a more morally committed attitude from him. From their legal standpoint willing and reflective acceptance shows sufficient respect for their authority. ${ }^{41}$

The Laws' account of Socrates' agreements applies to all citizens. For they take all those who remain in Athens after they have become acquainted with its legal system to have agreed by action to their authority (51e4). So, the Laws expect their citizens to willingly and reflectively accept their authority (irrespective of their motive for doing so) but they do not demand that they morally endorse it. The Laws' focus on willing and reflective acceptance is prudent from both a jurisprudential and a political point of view. Given that the Athenian democracy required the active participation of the whole body of citizens in the administration of justice and in political decision-making, the Laws reasonably demand that each citizen possesses reflective understanding of the workings of the legal system and does not merely habitually obey them. Furthermore, a demand that each citizen critically or at least uncritically endorses the democratic legal system would be politically unrealistic. On the one hand, it is impossible to check the true political commitments of each individual citizen. On the other hand, it would be futile to expect that aristocratic and oligarchic values could be eradicated from the souls of descendants of the old nobility and the wealthy. ${ }^{42}$ Political pragmatism suggested that the Athenian democracy stood the best chance of surviving by

${ }^{41}$ I take Socrates' willing and reflective acceptance of the authority of the Laws to be roughly equivalent to what Hart's takes to be non-moral acceptance of law. As he puts it: “...it is not even true that those who do accept the system voluntarily, must conceive of themselves as morally bound to do so, though the system will be most stable when they do so." (HLA Hart, The Concept of Law (Clarendon Press, 1994) at 203.)

${ }^{42}$ For a developmental account of the aristocratic and oligarchic ideology see Walter Donlan, The Aristocratic Ideal and Select Papers (Bolchazy-Carducci Publishers, 1999). 
safeguarding that its internal enemies would accept its laws rather than by demanding a complete change of their political ideology.

In the last two sections I analysed the Laws' account of their authority. If my analysis is correct, then in their speech the Laws explain what the authority of the Athenian law consists in. Whether their explanation correctly represents the Athenian citizens' understanding of the authority of the Athenian law is not an issue I can discuss here. For the purposes of this article the safest assumption to make is that this explanation represents the reflections of Plato, as the author of the Crito, on the theory and the ideology of the Athenian legal system.

6. The Laws on the relation between law and morality

I would like to conclude by examining what the Laws' account of their authority entails about their views on the relation between law and morality:

First, the Laws are best understood as claiming to have moral (practical) authority, that is, the normative power to morally bind the citizens in following or avoiding specific courses of action. Furthermore, their moral authority is supreme: the reasons of obedience that they create override all other conflicting considerations including moral considerations. That is, their command that the citizens do $X$ makes doing $X$ the overriding duty of the citizens even when in the absence of their command the balance of moral reasons of the citizens favours abstention from doing $\mathrm{X}$.

Some scholars understand the Laws to be committed to a conventionalist view of morality according to which they are the standard of justice. ${ }^{43}$ But that interpretation cannot be right. For if the Laws took their commands to be the standard of justice, their claims to allow the citizens to persuade them about "the nature of what is just" ( $\hat{e}$ to dikaion pephuke, $51 \mathrm{c} 1$ ) or to persuade them "if they do not do anything well" (ei mê kalôs ti poioumen, 51e8) would not make sense. By allowing the citizens to persuade them they acknowledge (a) that the content of at least some of their commands may be unjust and (b) that the citizens, rather than the Laws, may be correct about the justness of individual actions. Neither (a) nor (b) are compatible with the Laws' holding that justice is nothing other than what they command.

Second, the Laws do not ground their moral authority on some relevant epistemic moral superiority that they may possess. For example, they do not claim moral correctness (that is, that they on the whole promote justice or fairness in society), or superior knowledge on how to benefit the city. Rather they provide as grounds for their authority (a) their superior moral status and (b) the agreement ${ }_{\mathrm{A}}$ of the citizens.

A defence of the authority of law based on (b) can be classified as an argument for political obligation based on tacit consent. The shortcomings of that argument are wellknown especially as applied to contemporary political societies. I only note here that during the time the Crito was written emigration was a more meaningful alternative than it is nowadays for citizens who disagreed with the constitution of their city and there are historical

\footnotetext{
${ }^{43}$ See, for example, Young, supra note 2 at 24-29.
} 
examples of groups of citizens who emigrated after falling out with those who held power in their cities. ${ }^{44}$ So, an argument grounding the authority of law in ancient Athens on tacit consent may have more bite than a corresponding argument about the authority of law in modern and contemporary political structures.

How should we understand (a) as a ground for the authority of the Laws? According to the standard interpretation of the Laws' analogy of their status to the status of begetters and nurturers the relevant operative concepts are gratitude and reciprocity. ${ }^{45}$ The idea is that the Laws are willing benefactors of the citizens who in return owe them a duty of gratitude and have to reciprocate for the benefits that they received. But though that interpretation makes good sense of the nurturer analogy (as the provision of education may be plausibly considered by the ancient Greeks to be a benefit offered out of good will for which one may be grateful) it fails to capture the essence of the begetter analogy which is the one the Laws primarily focus upon (50e7-51c5). Gratitude cannot fully capture the Greek conception of the normative bond between biological parents and children. Though gratitude is normally apposite only when the benefactor acts out of good will, for the ancient Greeks a child owes special duties to his biological parents even when the latter show no form of good will towards him and may have actively tried to harm him. Oedipus is a famous case. His father, Laius, tried to kill him when he was born but Oedipus (and everyone else) still felt his parricide as a most hideous crime, a 'pollution' (miasma). Laius had clearly no good will towards Oedipus and Oedipus could hardly be considered to be under a duty of gratitude towards Laius; but his murdering his biological father even in self-defence and in ignorance of his identity was a most morally despicable act.

Plato endorses the relevant Greek conception of the normative bond between biological parents and children. In the Laws the crime of parricide in anger is greater in gravity than the crime of infanticide in anger. For the latter crime the punishment involves purification and exile for three years (868c5-8); for the former, unless the parents pardon their offspring before they die the punishment is death (869c5-6). Furthermore, Plato adds that killing one's begetters cannot be excused or receive a lesser punishment than death even when one is acting in self-defence (869b7-c5).

So, the Laws should be understood to assume that the mere biological bond between begetters and offspring has such severe normative implications that renders the latter morally subordinate to the former. The analogy of the Laws with human begetters purports to carry those severe normative implications. There is little doubt that that analogy was part of the ideological imagery of Athenian democracy. But what do the Laws think supports the analogy? Unfortunately, the analogy is thinly sketched so our answer to that question would have to be rather speculative. The Laws refer to the legal norms regulating the institution of marriage in Athens in order to illustrate the point of the analogy. One of the most important

\footnotetext{
${ }^{44}$ Especially within the context of what is known as Greek colonisation for which see Oswyn Murray, Early Greece (Fontana Press, 1993) at 102-23.

${ }^{45}$ See, for example, Walker, supra note 3.
} 
function of those marriage laws was to determine citizenship rights. ${ }^{46}$ For example, from the middle of the $5^{\text {th }}$ century only those whose both parents were Athenians qualified for Athenian citizenship. Those laws may be considered responsible for the nexus of one's political rights and duties that determined how one operated in the city. Taking that consideration into account the point of the analogy between begetters and the Laws could be that as the former are responsible for one's biological existence, that is, one's ability to operate as a biological agent, so the latter are responsible for one's civic existence, that is, one's ability to operate as an agent in a city. As the mere existence of a biological bond with their begetters irrespective of whether they are motivated by good will towards their children makes the children morally subordinate to them so the mere existence of the civic bond with the Laws irrespective of how well-disposed they are towards the citizens makes the citizens morally subordinate to the Laws (and indeed even more so, if we believe with the Laws that one's membership of a political society is more important than one's biological existence). If that is the focus on the analogy, the Laws merely presuppose its truth (probably treating it as an ideological belief firmly held by the Athenian citizens) as opposed to arguing for it.

Thus, the Laws' arguments for (b) ultimately rest on particular moral intuitions about the normative implications of the biological bond between begetters and children and an analogy between begetters and the Laws, which, though probably prevalent in the mind of the Athenian citizens, is neither sufficiently articulated nor properly defended in their speech. A proper assessment of the validity and force of those arguments in their historical context need to take those considerations into account.

Finally, even though the Laws claim that their legal directives are moral reasons that override any conflicting moral reasons that the citizens might have independently of their commands, the fact that they allow persuasion indicates that they at least 'aspire' that their commands reflect the balance of moral reasons independently of their commands as assessed from the moral standpoint of the citizens. In that respect the Laws differ from the more authoritarian counterparts that forbid not only disobedience but also any attempt to change their legal commands through persuasion. The Laws do not explain why they have this aspiration. A plausible explanation is that they believe that the convergence between their legal standpoint and the morality of the citizens will bolster the citizens' allegiance to their rule in the long-run. So, they allow the citizens to try to persuade them and, if they believe that they can accommodate a particular substantive moral position within their system of legal rules, they may retract a legal directive or change a legal statute.

That aspiration of the Laws does not, nevertheless, take precedence over their desire to safeguard their rule over the citizens in the short-run. So, they do not go as far as permitting disobedience or even presenting the attempt to persuade them as a moral duty of the citizens. They may have good pragmatic reasons for stirring away from either paths. The elevation of the attempt to persuade to the status of a moral duty and the public recognition of the moral permissibility of at least some acts of disobedience may create in the citizens an

\footnotetext{
${ }^{46}$ For an illuminating discussion of marriage laws and citizenship rights see ARW Harrison,
} The Law of Athens, vol 1 (Clarendon Press, 1968) at 61-68. 
ethos of moral inquisition which could undermine the effectiveness of the law's regulating the affairs of the city.

To sum up, the speech of the Laws contains a philosophically refined theory about the authority of law. The main tenets of that theory concern the behaviour and mental attitude that law demands from its subjects and the relation between law and morality. As I tried to show, in order for the Laws' theory about the authority of law to be properly analysed it needs to be located in its pertinent historico-legal context, namely, the context of the Athenian legal system, and philosophical context, namely, the context of Platonic philosophy. 